\title{
Possibilities of Using Geographic Products in Tasks of Military Engineering
}

\author{
Martin SEDLÁČEK ${ }^{1}$, Filip DOHNAL ${ }^{2}$ \\ ${ }^{1}$ Department of Engineer Support, Faculty of Military Leadership, University of Defence, Address: Kounicova 65, \\ 66210, Brno, Czech Republic \\ ${ }^{2}$ Department of Military Geography and Meteorology, Faculty of Military Technology, University of Defence, \\ Address: Kounicova 65, 66210, Brno, Czech Republic
}

E-mails: ${ }^{1}$ martin.sedlacek@unob.cz; 2 filip.dohnal@unob.cz

\begin{abstract}
This paper deals with the possibility of using geographic products in the Army of the Czech Republic for a purpose to create more efficient forms of geographic presentations with more dynamics and interaction, which can facilitate and accelerate a planning process of staff members in the selected tasks of military engineering. At present, there is no map in the Czech Army Corps of Engineers with the possibility of interaction, which would take into account the issue of tasks of military engineering.
\end{abstract}

KEY WORDS: geographic product, geographic support, interaction, maps, military engineering.

\section{Introduction}

At the present, the development of information and communication systems is desirable to exploit their potential and advantages and to seek opportunities for integration of these technologies also in the military field [1, 2, 3]. In the Army of the Czech Republic (ACR) is the information system of land forces called Information system of Command and Control (IS VR PozS), which does not fully reflect the needs of the Czech Army Corps of Engineers (CACE). For the needs of CACE not only at the tactical level of command is appropriate to have its own engineer subsystem command and control [4], which will take into account the issues and details of military engineering, because the current IS VR PozS does not deal with it. If the IS VR PozS could be relevant, it must contain important data and information, which is then processed by members of the military staff. This data and information should be used to plan and prepare tasks of engineer support in order to facilitate of obtaining and sharing information and to make staff members more efficient in use of less time [5]. In most cases, the information is based on known background and, in the course of conducting a military operation, activities in the operational environment.

Maps are an important source of geographic information for the common operational picture (COP). The maps contain elements of the natural and cultural environment that are subject to natural developmental changes, or even transformations as a result of human activity. For this reason, there must be updated the maps. Changing the natural environment, communications and infrastructure can, as a rule, be much greater in the conduct of a military operation, as it is influenced by its own troops, enemy and civilian [6]. In the case of a combat operation with the character of tactical activity (attack, defense), the changes are the most important, as shown by historical facts, but also by current conflicts in the world [7].

Digital maps with added interaction and dynamics functionality can reflect the importance of interrelationships between natural and artificial elements of the landscape [8]. It is convenient to include more relevant information in a given point object from a landscape. The map can then contain a large amount of data and information, but it is clear and readily available without having to do a recoinnassance or to gather other data. The graphs, plans, drawings and photos included in the data structure of the database can partially replace, for example data-intensive digital 3D maps. The displayed data above the base map with the created database relation to other sources of information can fully secure and replace the phase of the general engineer recoinnassance or at least this will accelerate the recoinnassance and make the information more relevant $[9,10]$.

The purpose of the article is not to propose final technical compatibility with IS VR PozS and interoperability with other NATO systems, but to propose ways in which the engineer subsystem of command and control in the ACR can develop. The relevance of using the user interface with the interactive map is described in the specific task of military engineering.

\footnotetext{
${ }^{1}$ Corresponding author.

E-mail address: martin.sedlacek@unob.cz.
} 


\section{Geographic Support in ACR}

The ACR Geographic Service (GeoSl ACR) provides geographic support at individual levels of command. The aim of geographic support is to ensure the availability of geographic products and services to users for planning and conducting operations, organizing interoperability with other military forces, or ensuring the functionality and efficient use of command and control systems or weapon systems. The executive unit is the Military Geographical and Hydrometeorological Office (VGHMUr), based in Dobruška, which provides information collection, creation and management of geodetic, cartographic and geographic data and maps and special databases [12].

The current trend in the development of modern technologies increases demands on the availability of various types of information for the feasibility of the ACR. Geospatial information is one of the key. These are mainly geodata from the territory of the Czech Republic or from foreign areas where Czech soldiers operate in foreign operations. The activity of the CACE can be concentrated in places both in urban areas and out of them. For this reason, it is necessary not to concentrate only on a certain part of the landscape sphere, but on all its elements such as water, vegetation, relief, soils, roads, settlements and other objects of the whole infrastructure [6, 11]. The GeoSl ACR [12] is intended to secure this and other geographic information of the ACR.

\subsection{Products of ACR Geographic Service}

Products are all creations required for geographic support tasks. It is divided into printed map products, digital geospatial data, military geographic documents and geoinformation technologies (applications). GeoSl ACR creates or secures printed maps especially for ground and air operations. These maps are intended for the planning and management of combat operations commanders and staffs at all levels of command and control, or for practical navigation and orientation in the field. Digital geospatial data is designed to secure command and control systems, to operate weapon, navigation, reconnaissance and simulation systems, to conduct field analyzes, and to create map products.

For the creation of engineer subsystem command and control is more favorable in terms of efficiency to use data in digital form. Under the management (or partial management) of VGHMUr there are several digital geospatial databases, which include, among others [13]:

- Digital Landscape Model 25 (DMU 25) - vector data covering the territory of the Czech Republic and the surrounding area with a resolution level, accuracy and degree of generalization corresponding to the scale of map 1:25,000;

- Digital Landscape Model 100 (DMU 100) - vector data covering the territory of the Czech Republic and the surrounding area with a resolution level, accuracy and degree of generalization corresponding to the scale of map 1:100,000;

- Vector Map Level 0 (VMAP0) - vector data covering the whole world with a resolution level, precision and degree of generalization corresponding to a scale of 1:1,000,000;

- Vector Map Level 1 (VMAP1) - vector data covering the whole world with a resolution level, accuracy and degree of generalization corresponding to the scale of map 1:250,000;

- Digital Terrain Model 1 (DMR 1) - contains elevation field data for the territory of the Czech Republic and the surrounding area in a regular network $1 \times 1 \mathrm{~km}$;

- Digital Terrain Model 2.5 (DMR 2.5) - contains elevation field data for the territory of the Czech Republic and the surrounding area in a regular network $100 \times 100 \mathrm{~m}$;

- Digital Terrain Model 3 (DMR 3) - contains elevation field data for the territory of the Czech Republic and the surrounding area in a regular network $10 \times 10 \mathrm{~m}$;

- Digital Terrain Model of the Czech Republic of the 4th generation (DMR 4) - contains elevation data for the territory of the Czech Republic and the surrounding area in a regular $5 \times 5$ metwork;

- Digital Terrain Model of the Czech Republic of the 5th generation (DMR 5) - contains elevation data for the territory of the Czech Republic and the surrounding area in the irregular triangular network TIN;

- Digital Surface Model of the Czech Republic of the 1st generation (DMP 1) - contains a representation of the territory of the Czech Republic including buildings and vegetation cover in the irregular triangular network TIN;

- Digital Terrain Elevation Data Level 0 (DTED 0) - contains elevation terrain data covering the entire world in a regular network of points defined by geographic coordinates in step of 30 arc-second;

- Digital Terrain Elevation Data Level 1 (DTED 1) - contains elevation terrain data covering the entire world in a regular network of points defined by geographic coordinates in step of 3 arc-second;

- Digital Terrain Elevation Data Level 2 (DTED 2) - contains elevation terrain data covering the entire world in a regular network of points defined by geographic coordinates in step of 1 arc-second; 
With regard to the tasks of military engineering, it is convenient to use as accurate data as possible. Of the above, it is best to use data from DMU 25 and DMR 5 (or DMP 1) for creating applications of the engineer command and control subsystem in the Czech Republic. Taking into account data demands, it is possible to select less demanding data sets with geographic information.

\subsection{Use of Army Geographic Products in the ACR}

At different levels of command and control, geographic information is required to match the spatial accuracy, resolution, or frequency to tasks. Some products and geographic information are classified and not commonly used. For the strategic level, usually at the General Staff level, geographic information evaluating mainly the area of interest outside the Czech Republic is processed. Outputs including not only physical geographic but also socio-economic information are usually not very detailed due to the low spatial resolution and are the basis for the initial framework assessment of the operational environment. At the operational level, geographic information is focused on defining the operational environment and describing the physical-geographic and socio-economic spheres, and allows the assessment of the complex impact of space on the operation. At the tactical level, geographic information is focused on analyzing the military aspects of the terrain and assessing the impact of the terrain on the conduct of the operation.

For the needs and tasks of the geographic service and other military units, VGHMUr has developed the MAPY ACR application, which allows access to digital geospatial data in the form of a web or desktop application. Thus, the ACR members have access to geographic information. Another possible way is to request the necessary geographic data directly from VGHMUr [14].

The MAPY ACR application uses web (WMS, WMTS, WFS) or desktop services to display the map layers. The base layers change dynamically according to the scale series. For the Czech Republic, it goes from OpenStreetMap (small scale), through Military and Topographic Maps of the Czech Republic to Topographic Map 1:25,000 (medium / large scale). It is also possible to use as a base layer satellite and aerial images (in the Czech Republic on a large scale) or visualize the shaded relief of the terrain in an adjustable degree of transparency.

The MAPY ACR application also consists of modules that serve to extend functionality. Individual modules were created on the basis of requirements of various ACR units. These modules include, for example the Howitzer Module, which creates a superstructure and the physico-mathematical model of the artillery device is visualized in the form of a fire network. The analogy is for the Endangered Areas Module, whose output is the marking of the firing range of selected military weapons. Other modules Geodetic Points and Earthquakes, whose superstructure layers allow to display information about geodetic points or seismic phenomena through spatial queries, for example in the form of pop-ups, represent a further measure of interaction in the map environment. Also worth mentioning is the Terrain Profile Module, which uses a geoprocessing service to create and visualize the elevation profile above the relief model.

Geographic data produced by the GeoSl ACR are also used, for example in the Fire Distribution Centre (FDC) RACCOS, which is intended as a nodal element of the automated command and control of fire (ASVRP). It is used for the purposes of air defence missile. Topographic Support RACCOS is software that allows fire officers to access a wide range of geographic information, view and use it when working with graphical and database-oriented applications before, during, and after combat operations. Geographic layers are divided into four folders according to the type of source data:

- $\quad$ ICAO-CZ folder - transparent layers of aerial map;

- Vector folder - geographic layers of the vector map;

- Raster folder - set of raster maps;

- Relief folder - elevation models in the form of a grid.

The default installation of the map database covering the needs of the user in the Czech Republic consists of several products, including products issued by GeoSl ACR. They are:

- Vector databases DMU 25, DMU 200, VMAP 1 for the Czech Republic;

- RETM 25 (Raster equivalents of Topographic maps 1:25,000) for military training areas, aerodromes and shooting ranges;

- $\quad$ RETM 50, RETM maps of the Czech Republic;

- REVM 500 (Raster equivalents of Military maps 1:500,000) and DMR 1 of Central Europe;

- REVM 1 MIL and DMR 2.5 of European territory.

Map products in the system serve as base maps without any interactivity. Above the base map, the software allows firing officers to make only drawings and position marks on a dynamically changing scale.

Another specialized component of the ACR, which uses geographic products to fulfill its tasks, is the 31 st Regiment of Radiation, Chemical and Biological Protection. They use CBRN-ANALYSIS commercial software, 
recognized by NATO experts as a leading automated application, to defend against weapons of mass destruction, to anticipate hazards, warn and report the consequences of nuclear, biological and chemical incidents. Digital maps, satellite and aerial imagery serve as base maps, over which users can draw location markers and analyze. Only in one case is geographic data used to analyze the area, in search of the optimal route to overcome the contaminated area.

Another area of use of geospatial data is constructive simulation systems in the preparation of commanders and staffs members as part of training on a tactical simulator. In an OTB (OneSAF Testbed Baseline) system, individual persons, vehicles, or technical means are expressed by an entity that simulates their activity depending on physical conditions, terrain characteristics, weather conditions and technical constraints imposed by the characteristics of a real vehicle (weapon system). Geographic reality is represented in the system by DMR 2.5 and DMU 25, where the relief characteristics (eg. slope) and attributes of individual objects taken from DMU 25 enter into the simulation as factors influencing the behavior of individual entities [15].

\subsection{Geographic Support of the ACR in Cooperation with the Integrated Rescue System}

Integrated Rescue System (IRS) parts according to Act No. 239/2000 Coll. [16] are divided into main parts (Fire Rescue Service, Emergency Medical Service and the Police of the Czech Republic) and other parts, including, the allocated forces and resources of the ACR and others. Some GeoSl ACR products belong to the Government Regulation No. 430/2006 Coll. [17] among National Map Series, which according to $\S 4$ par. (b) used for the purposes of crisis management and the IRS. From the full range of map products that are enshrined in the aforementioned Government Decree, civilian and military geographic products can be used in various forms.

The Fire Rescue Service of the Czech Republic (HZS CR) as a main part of the IRS and the founder of the permanent service of emergency call centers manages its Central Data Storage (CDS HZS), where is collected geospatial data from The Czech Office for Surveying, Mapping and Cadastre, Road and Motorway Directorate, Czech Statistical Office, Czech Railways, joint stock company CEPS, Czech Post, ACR, T. G. Masaryk Water Research Institute, p. r. i etc.). However, in the ACR, which provides data to the Fire Rescue Service of the Czech Republic, the reverse data flow is no longer legally addressed. Therefore, the ACR units cannot primarily use the data from the CDS HZS for the preparation of units in case of need to perform tasks within the IRS. Only in case of joint exercises of IRS units or during direct deployment.

\section{Interaction in Tasks of Military Engineering}

Digital map products and their graphical visualization are important in terms of facilitating and accelerating the work of staff members in the planning process of the military task force $[18,19]$. They can facilitate the transfer and sharing of information, promote efficient transportation of people and materials, evaluate designing, increase work efficiency, minimize costs and save time [20]. Tasks of military engineering affect the conduct of military operations because of the support of combat units, combat support units or even combat security units. The scope of the tasks of military engineering does not only concern the ACR land forces, but also intervene and influence the capabilities of the air force (for example maintenance of existing airfields). It can be stated that the fulfillment of tasks of military engineering through the CACE affects the activity of all types of units in the ACR.

\subsection{Classification of Military Engineering}

To better understand the classification of tasks in military engineering, it is important to define allied documentation that takes into account the nature of the military engineering that results in the individual tasks. The primary publication ATP-3.12.1. Allied tactical doctrine for military engineering for NATO engineer units describes the main principles and serves as a mean to prepare and execute military engineering at the tactical level of command [21]. All of the tasks, capabilities, and procedures described in this document have a significant or supportive role for each function. Joint Function are domains that affect the nature of the operational environment. That is:

- $\quad$ command \& control;

- manoeuvre \& fires;

- intelligence;

- force protection;

- $\quad$ sustainability

- CIMIC;

- Information operations.

The tasks of military engineering are fulfilled across the entire operational environment and thus apply to all joint functions. However, the functions of manoeuvre \& fire, force protection and sustainability are always taken into account in carrying out the tasks of military engineering and have significant consequences [19]. Definition of tasks of 
military engineering performed by the ACR (CACE), are also taken into account [22, 23]. Figure 1 shows the direct links between joint functions, engineer roles and tasks.

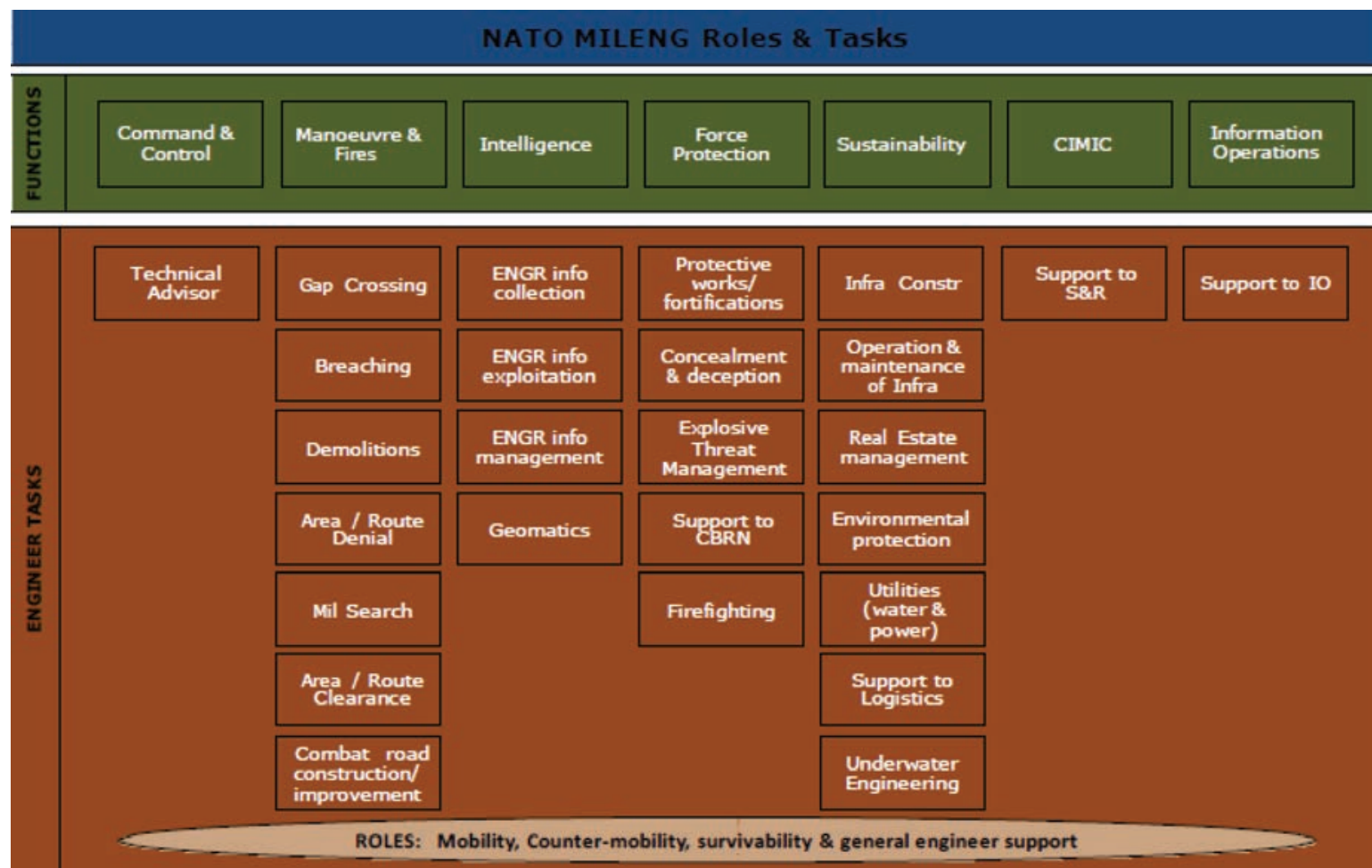

Fig. 1. Joint functions, engineer roles and tasks.

Source: [2]

Table 1 shows a detailed overview of the tasks of military engineering in relation to engineer roles. By identifying all tasks, it is possible to determine the potential use of geographic and other important technical data in terms of interaction functionality. Table 1 highlights (in italics) those tasks for which the interaction could be used.

Table 1

Source: [4], elaboration: authors

\begin{tabular}{|c|c|c|}
\hline \multicolumn{2}{|c|}{ MILENG Roles } & Task of engineer support \\
\hline \multirow{2}{*}{\multicolumn{2}{|c|}{$\begin{array}{l}\text { Command and control of military } \\
\text { engineering }\end{array}$}} & order to meet the engineer task - issued from the company level below \\
\hline & & report - request to add logistic material \\
\hline \multicolumn{2}{|c|}{ Situational overview } & status reports \\
\hline \multirow[t]{17}{*}{ Mobility support } & \multirow{4}{*}{$\begin{array}{l}\text { Countermine and } \\
\text { counter obstacle } \\
\text { operations }\end{array}$} & engineer recoinnassance \\
\hline & & clearance of mined areas introduced manually and mechanically \\
\hline & & area clearance \\
\hline & & clearance of mined areas introduced remotely \\
\hline & \multirow[t]{9}{*}{ Routes } & engineer recoinnassance of roads and objects on them \\
\hline & & identification and marking of roads \\
\hline & & roads maintance \\
\hline & & developing and improving of roads \\
\hline & & setting up detours \\
\hline & & removal of non-explosive obstacles on roads \\
\hline & & culverts maintance \\
\hline & & bridges maintance \\
\hline & & removal of explosive obstacles on roads \\
\hline & \multirow[t]{4}{*}{ Gap crossing } & wet gap recoinnassance \\
\hline & & building of bridges \\
\hline & & establishment of facilities for bridges \\
\hline & & dry gap crossing \\
\hline
\end{tabular}




\begin{tabular}{|c|c|c|}
\hline \multirow{7}{*}{$\begin{array}{l}\text { Counter-mobility } \\
\text { support }\end{array}$} & \multirow{5}{*}{$\begin{array}{l}\text { Assembly side } \\
\text { protection }\end{array}$} & engineer recoinnassance \\
\hline & & emplace the minefields introduced manually and mechanically \\
\hline & & emplace the explosive obstacles on the roads \\
\hline & & emplace the minefields intruduced remotely \\
\hline & & emplace the non-explosive obstacles \\
\hline & \multirow{2}{*}{$\begin{array}{l}\text { Emplacing } \\
\text { obstacles on the } \\
\text { enemy roads }\end{array}$} & emplace the explosive obstacles on the roads \\
\hline & & emplace the minefields intruduced remotely \\
\hline \multirow{15}{*}{$\begin{array}{l}\text { Survivability } \\
\text { support }\end{array}$} & \multirow{10}{*}{$\begin{array}{l}\text { Preparation and } \\
\text { construction of } \\
\text { protective objects } \\
\text { in assembly area }\end{array}$} & engineer recoinnassance for building of protective objects \\
\hline & & building of observatories, check-points \\
\hline & & establishing bases of troops of all kinds \\
\hline & & maintenance of military bases of all kinds \\
\hline & & establishment of forward airfields \\
\hline & & maintenance of existing airfields \\
\hline & & building and strengthening of field fortifications \\
\hline & & building firing positions for artillery and combat units \\
\hline & & building command places \\
\hline & & $\begin{array}{l}\text { establishment of storage areas and landfills for ammunition and other } \\
\text { material }\end{array}$ \\
\hline & \multirow{3}{*}{$\begin{array}{l}\text { Camouflage and } \\
\text { concealment }\end{array}$} & camouflage of command places \\
\hline & & $\begin{array}{l}\text { camouflage of storage areas and landfills for ammunition and other } \\
\text { material }\end{array}$ \\
\hline & & camouflage of supply roads \\
\hline & \multirow[t]{2}{*}{ Deception } & building of deceptive positions \\
\hline & & builging of deceptive objects and targets \\
\hline \multirow{10}{*}{$\begin{array}{l}\text { General engineer } \\
\text { support }\end{array}$} & \multirow[t]{2}{*}{ Water supply } & engineer recoinnassance for water extraction \\
\hline & & building of water treatment places and distribution sites \\
\hline & \multirow{6}{*}{$\begin{array}{l}\text { Construction } \\
\text { and maintenance } \\
\text { of utilities and } \\
\text { structures }\end{array}$} & $\begin{array}{l}\text { engineer recoinnassance for the implementation of general engineering } \\
\text { support tasks }\end{array}$ \\
\hline & & building of air landing facilities \\
\hline & & $\begin{array}{l}\text { airfield damage repair (ADR); building, repair and maintance of logistics } \\
\text { infrastructure }\end{array}$ \\
\hline & & building, repair and maintenance of railways \\
\hline & & building, repair and maintenance of ports \\
\hline & & building, repair and maintenance of accommodation facilities \\
\hline & \multirow[t]{2}{*}{ EOD } & recoinnassance for EOD/IEDD \\
\hline & & EOD/IEDD tasks, including CBRN \\
\hline
\end{tabular}

\subsection{Limitations of the Use of Interaction in the User Map Interface}

The possibility of using the interaction in the map interface applies only to selected tasks of military engineering. The first assumption is that these tasks are connected with location at one specific point in the map. For this reason, the information from the interactive map is relevant to one point. An example might be the task of military engineering - culverts maintance. A culvert is one point at which symbol, notes, photos and diagrams can be recorded. In most cases it is not possible to record constant data that would be the same for longer line barriers, such as roads, rivers, as the nature of these line elements varies in length. The second assumption for the creation of maps with a certain degree of interaction in carrying out the tasks of military engineering is the data and information that is already available from various sources. Information, which is available only during the conduct of combat activities, are usually up to additionally evaluated according to the change of the operating environment. Therefore, as a rule, it is not possible to create interactive maps that are relevant to the tasks of military engineering directly related to the conduct of changing combat activities.

The indicated tasks (in italics) of military engineering from Table 1 are described in using information and sharing them through the proposed map application. Some tasks interact with each other across engineer roles and functions. Therefore, their importance in terms of the use of interactive maps is increasing: 
- $\quad$ engineer recoinnassance of roads and objects on them - in terms of the possibility of using an interactive map, there will be more objects on the road as points, rather than the whole road; these may be tunnels, culverts, bridges, railways crossings, underpasses, dams; for example, diagrams, profiles, photos, side views and ground plans can be displayed;

- roads maintenance - possible use while maintaining the same top and basis of material on roads between two points; an example may be a longitudinal and cross-sectional view of the communication with the technical description, photographs and other diagrams;

- $\quad$ setting up detours - the possibility of using is limited due to line elements, but it is possible to display bridges and culverts that meet the limit load values for a given type of technique within the detour and describe them;

- culverts maintance - use of interaction when displaying culvert data (longitudinal section and ground plan view supplemented with photographs);

- bridges maintance - the possibility of using interactive maps; in order to strengthen, repair and maintain the bridge, it is convenient to use the information by means of an interactive map that offers photographs, description, ground plan, side view to bridge;

- $\quad$ engineer recoinnassance of wet gap crossing - a significant possibility of using data on water obstacles that are already known, such as modified river basins, their profile with data, long-term average water level for a given season due to fording, sailing or bridging, long-term average water flow and current velocity for a given season, or images of weirs and other technical structures on a water obstacle, which could potentially affect the mobility of military vehicles when crossing wet gap;

- building of bridges - the limited possibility of use due to variable data of line barriers (rivers) and in the case of conducting combat activities during the action of enemy; there is the possibility to use them at points of hydrological stations where data are known in advance for the building a bridge or near permanent road bridges for which documentation is kept;

- emplace the explosive obstacles on the roads - the possibility of using interactive map to display permanent destruction facilities that occur on some types of bridges and sections of highways;

- maintenance of military bases of all kinds - possibility to use schemes, infrastructure plans, photographs and other plans from database;

- maintenance of existing airfields - use of plans, diagrams and photographs of existing and emergency airfields;

- $\quad$ engineer recoinnassance for water extraction - the possibility of using with sources, where the information about the resource yield is known, for surface water points with knowledge of water volume;

- building of water treatment and distribution sites - the possibility of use for line and surface water points, knowing the flow and volume of water;

- $\quad$ airfield damage repair (ADR); building, repair and maintenance of logistic infrastructure - possibility to use plans, diagrams and photographs of existing and emergency airfields, but also in the building of infrastructure by including the state of the infrastructure in the geographic database and their interactive visualization in the map window of the application;

- $\quad$ building, repair and maintenance of railways - the possibility of using primarily documents, diagrams, plans, side views, ground plans of railway bridges, but also by sharing information in the form of photographs about railway crossings.

\section{Design of Interactive Map Application for Planning and Fulfillment of Selected Task of Military Engineering}

The basic requirement in solving the tasks of military engineering is the selection of a suitable geographic database and subsequent display of data and information in the user interface. For the purpose of planning, command and control of the tasks of military engineering within the task force, it is best to use the vector database DMU 25 , which represents the most comprehensive geographic database used in the ACR. DMU 25 consists of individual layers belonging to one of these areas of the landscape (water; communications; pipelines, energy and telecommunications infrastructure; vegetation and soil cover; settlements, industrial and other topographic objects; borders and fences; terrain relief). Layers are further characterized primarily by their geometry and topology, as well as quantitative and qualitative information, which are clearly stored in the attribute table. Definitions of layers, object types and attributes can be obtained using the Catalog of Topographic Objects [24].

Table 2 shows the tasks of military engineering to which object types are assigned across layers. The visualization of individual types of objects with the support of interactivity in the possibility of displaying information about a given element increases efficiency in the decision making process of commanders and staffs. In all cases, these are only selected object types, as it is not necessary to include all objects in the map field for the analysis of the 
solved task. For better orientation in the map and clarity of the situation, it is advisable to supplement the map field with a base layer eg orthophoto, satellite image or topographic map.

Reciprocal link of the tasks of military engineering with object types according to DMU 25.

Codes represent semantic object types taken from DIGEST-2-0

\begin{tabular}{|l|l|l|l|l|l|l|}
\hline \multicolumn{2}{|l|}{} & \multicolumn{5}{|c|}{ Types of objects } \\
\hline 1 & engineer recoinnassance of roads and objects on them & BA010 & BE020 & BF510 & BI030 & BB190 \\
\hline 2 & roads maintance & BA010 & BB190 & BB999 & AP010 & AQ040 \\
\hline 3 & setting up detours & BA010 & BE020 & BE015 & BH020 & BH095 \\
\hline 4 & culverts maintance & BA010 & BE020 & $\begin{array}{l}\text { BF510 } \\
\text { BF010 }\end{array}$ & BH140 & BH030 \\
\hline 5 & bridges maintance & BH010 & BA010 & BE020 & BF510 & BI520, \\
BI020
\end{tabular}

Source: authors

Table 2 shows only a part of the object types for clarity of the table. Those that are essential are highlighted in italics. The types of objects that are not taken into account are irrelevant in the planning and execution of the task. Another reason for the selection is also a lower data intensity, which affects the sharing and distribution of data and information or their updating.

Table 3 shows the relationship of the task of military engineering with the attributes of each object type. The task is defined in terms of the need for knowledge of data and information for planning, command and control of the activity. Within certain types of objects, only some attributes are selected that are relevant for the commanders and members of staff. Attributes that are not taken into account are omitted for a clearer overview on the map and less data. Table 3 shows only a part of the object types with their attributes for clarity of the table.

Table 3

Definition of the military engineering task with link to attributes according to DMU 25

\begin{tabular}{|c|c|c|c|c|c|}
\hline Culverts maintance & BA010 & BE020 & $\begin{array}{l}\text { BF510 } \\
\text { BF010 }\end{array}$ & BB190 & BH140 \\
\hline \multirow[t]{2}{*}{$\begin{array}{l}\text { Types of objects affecting } \\
\text { the mobility of own troops } \\
\text { or also enemy. }\end{array}$} & BANK & DEPTH & $\begin{array}{c}\text { FLOW } \\
\text { CHARACTERISTICS }\end{array}$ & WATERFRONT & $\begin{array}{l}\text { RIVER, } \\
\text { STREAM }\end{array}$ \\
\hline & Attributes & Attributes & Attributes & Attributes & Attributes \\
\hline \multirow{9}{*}{$\begin{array}{l}\text { Assumption of interaction } \\
\text { - points on the base map } \\
\text { that show values in the } \\
\text { longitudinal and cross- } \\
\text { sectional view of the } \\
\text { culvert. Complemented } \\
\text { with photographs } \\
\text { of culverts in real } \\
\text { environment. }\end{array}$} & LOC & HDP & WD3 & LOC & HDP \\
\hline & HYC & $\mathrm{NKO}$ & HDP & HGT & EXS \\
\hline & HGT & PCO & SMC & MCC & $\mathrm{NKO}$ \\
\hline & MCC & TXT & WVA & $\mathrm{NKO}$ & PCO \\
\hline & NKO & & WVP & PCO & TXT \\
\hline & PCO & & $\mathrm{NKO}$ & TXT & \\
\hline & TXT & & PCO & & \\
\hline & & & TXT & & \\
\hline & \multicolumn{5}{|c|}{$\begin{array}{l}\text { Data affecting selection of culvert maintance (engineer accessories). There is link with } \\
\text { other tasks - setting up detours and building bridges (in the event of destruction of a } \\
\text { culvert or bridge). }\end{array}$} \\
\hline
\end{tabular}


Figure 2 shows the selected layers with object types for the given task of military engineering (culvert maintance) on real DMU 25 data. Figure 3 indicates a possible link of DMU 25 with objects in the geographic database. This is a design application according to the task of military engineering. The design of user interface is created from available data and information and display structures.

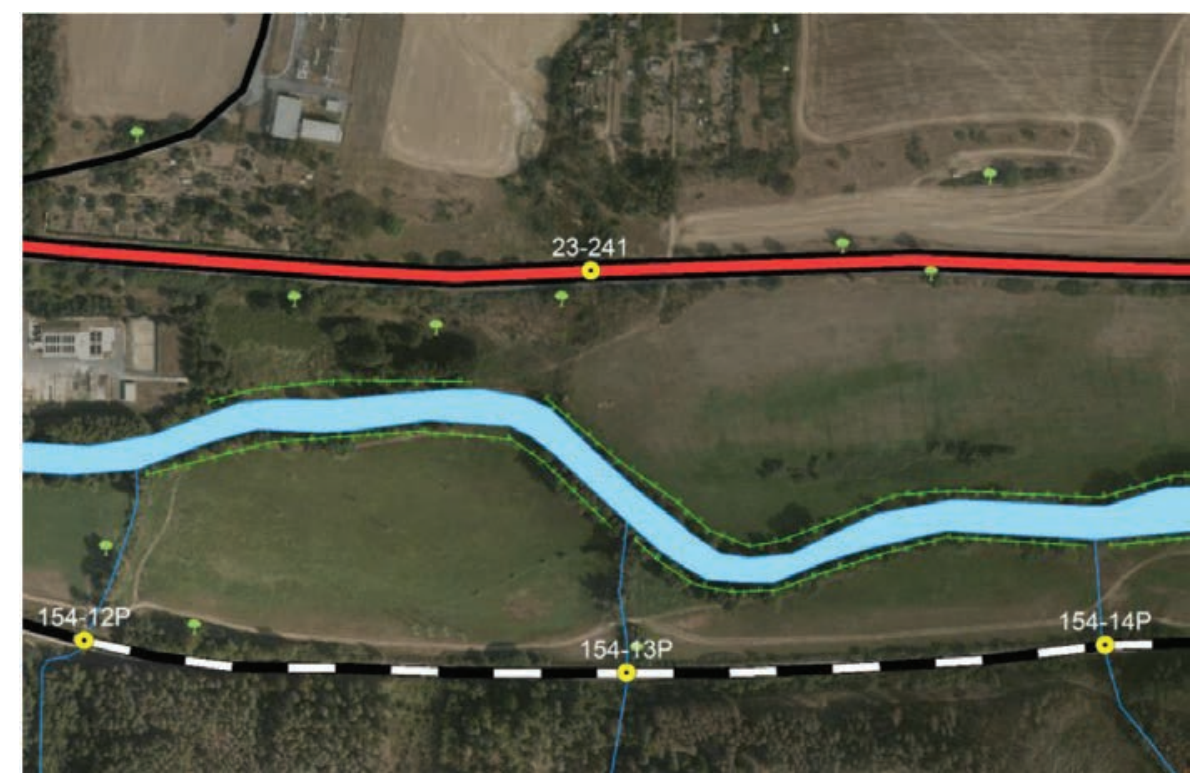

Fig. 2 Link of selected layers and object types in DMU 25 with orthophoto. Source: [25], elaboration: authors.

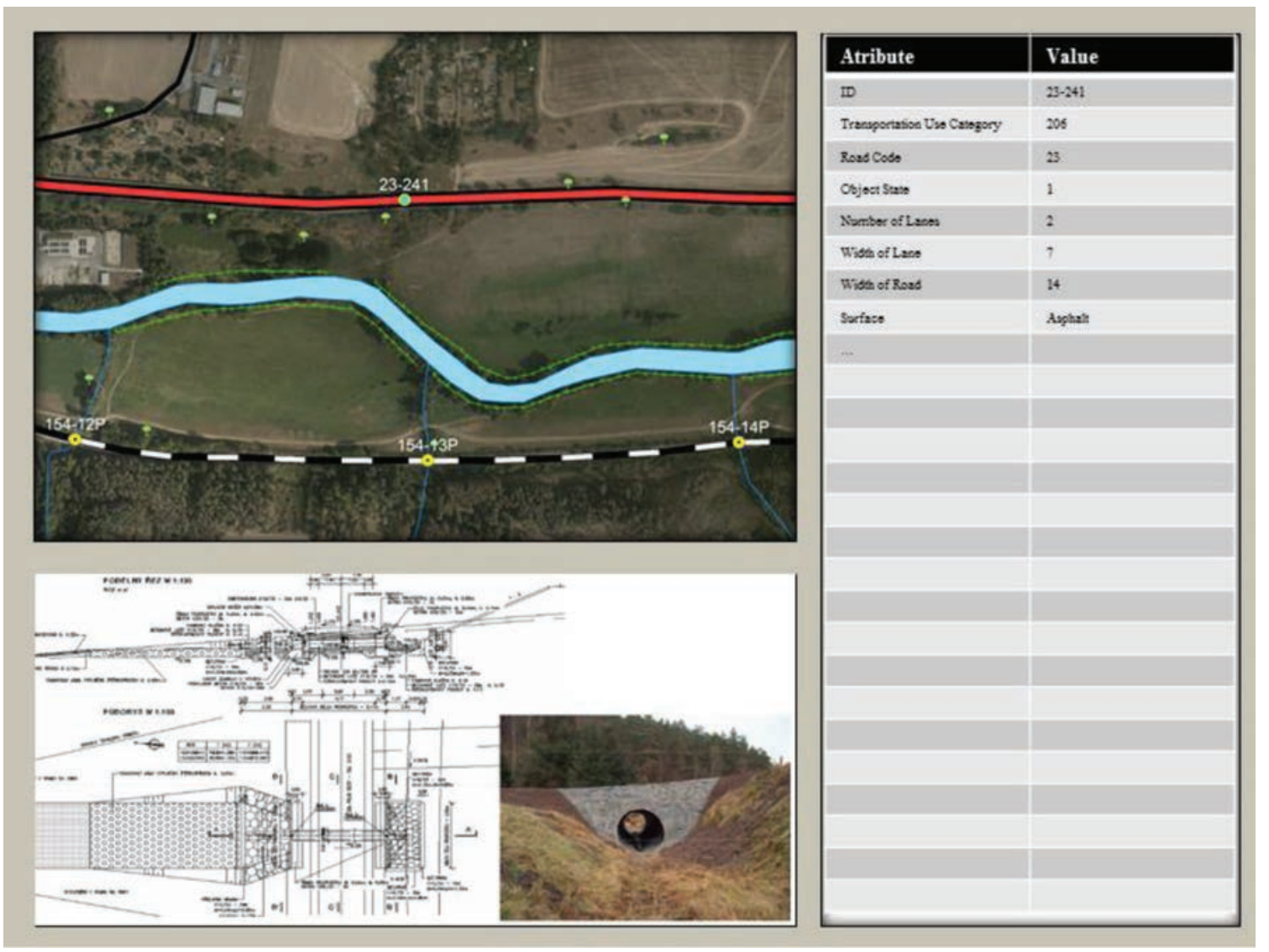

Fig. 3 Design of the user interface Zdroj: [25, 26], elaboration: authors. 


\section{Conclusions}

The tasks of military engineering are performed across the entire operational environment and generally concern all joint functions. This affects all types of troops. In planning and execution of tasks, information is required to support a proper understanding of the situation and analysis of the battlefield. Information is provided by the ACR Geographic Service, means of reconnaissance, intelligence and civilian population. For the needs of CACE the primary source materials are map products distributed from GeoSl ACR, ie VGHMUr. It is divided into printed map products, digital geospatial data, military geographic documents and geoinformation technologies (applications).

Within the ACR is used the IS VR PozS, which does not fully reflect the need of the CACE. In CACE is introduced engineer subsystem command and control, which allows to analyze only selected tasks of military engineerign - emplace the explosive obstacles and building and strengthening of field fortifications. However, these areas are not linked to data and information from geographic sources and therefore always require supplementation.

Data and information from maps are potential for the CACE to create mutual links with the tasks of military engineering. In this way, the data and information can be selected to analyze the task. Points in a map interactive application that are tied to important objects in the operational environment can be a transparent form of data and information representation. The CACE also performs tasks also within the IRS. At present, there is any legislative basis focused in sharing and providing geographic data and information in standard form between ministries and their institutions.Interactivity allows visualization of collected data and information at a given point, which is an important object of engineer recoinnassance. Planning of the task of military engineering does not replace the calculations, but provides primarily clearer form of data and information to perform a faster analysis of the task by the engineer staff memebers of task force.

\section{Acknowledgements}

This work was conducted within the framework of the scientific project "Application software for water crossing in ACR" and the defense research project DZRO K-210 NATURENVIR.

\section{References}

1. Christopher P., Clarke C. P., Triezenberg B. L., Manheim D., Wilson B., 2018. Improving C2 and situational awareness for operations in and through the information environment. Santa Monica, Calif.: RAND Corporation. Research report (Rand Corporation), RR-2489-OSD. ISBN 978-1-9774-0131-1.

2. Nohel, J. Possibilities of Raster Mathematical Algorithmic Models Utilization as an Information Support of Military Decision Making Process. In: Modelling and Simulation for Autonomous Systems. Cham, Switzerland: Springer: NATO Modelling and Simulation Centre, 2018, p. 553-565. ISSN 0302-9743. ISBN 978-3-030-14984-0.

3. Talhofer V., Hošková-Mayerová Š., Hofmann A. Quality of Spatial Data in Command and Control System. Gewerbestrasse 11, 6330 Cham, Switzerland: Springer International Publishing, 2019. 192 p. Studies in Systems, Decision and Control, 168. ISBN 978-3-319-94561-3.

4. Bielený R. Ženijní podsystém velení a řízení v podmínkách Network Enabled Capability (NEC). Brno : Univerzita obrany, 2014.

5. Rolenec O., Kopuletý M. Engineer Devices for Obstacle Breaching in Offensive Operations and Possible Application of Engineer Robots. In: International Conference on Military Technologies ICMT 2017. Piscataway, NJ 08854-4141 USA: Institute of Electrical and Electronics Engineers Inc., 2017, p. 200-206. ISBN 978-1-53861988-9.

6. Collins J. M. Military geography for professionals and the public. Washington, DC: National Defense University Press. 1998. ISBN 1-57906-002-1.

7. Cibulová K., Rolenec O., Garba V. A Selection of Mobility Support Engineering Devices of NATO Armies Usable in the Czech Armed Forces Combat Operations. In: Proceedings of International Conference of Military Technologies Brno 2019. Brno: Univerzita obrany v Brně, 2019, p. 855. ISBN 978-1-7281-4593-8.

8. Palasiewicz T., Kopuletý M. Advanced Military Robots Supporting Engineer Reconnaissance in Military Operations. In: Modelling and Simulation for Autonomous Systems. Cham: Springer, 2018, s. 285-302. ISSN 0302-9743. ISBN 978-3-319-76071-1.

9. Palasiewicz T., Skalický P., Kyjovský J., Zelený J. Possibilities of Modelling and Simulation in Military Engineering. In: Modelling and Simulation for Autonomous Systems. Cham: Springer, 2018, s. 402-409. ISSN 0302-9743. ISBN 978-3-319-76071-1.

10. Sobotka J. Comparison of elevation data of the Czech Republic for designing military constructions. Advances in Military Technology, 2013, vol. 7, no. 2, p. 57-63. ISSN 1802-2308. 
11. Rybanský M., Talhofer V., Bureš M., Šimková K. The influence of spatial database quality on modelling of vehicle movement in terrain. In: Proceedings of the 19th International \& 14th European-African Regional Conference of the International Society for Terrain-Vehicle Systems. Budapest: International Society for TerrainVehicle Systems, 2017, p. nestránkováno. ISBN 978-1-942112-49-5.

12. Hubáček M., Kovař́k V. Landscape: A Friend or Foe? In: Central Europe Area in View of Current Geography. Brno: Masarykova univerzita, 2016, p. 160-167. ISBN 978-80-210-8313-4.

13. Katalog geografických produktů, 2009. Praha: Ministerstvo obrany ČR, Geografická služba AČR.

14. Hába D. Mapová aplikace pro uživatele Armády ČR s využitím ArcGIS API for Flex. In: Konference GIS Esri v $\check{C} R 2014$ [online]. Praha: ARCDATA PRAHA, 2014 [cit. 2020-01-14]. Dostupné z: http://download.arcdata.cz/ konf/2014/pradnasky/prezentace/Haba_VGHMUr.pdf

15. Procházka D., Hubáček M., Rapčan V. Using ModSAF in Czech Army: The current status. In: 6TH World Multiconference on Systemics, Cybernetics and Informatics, vol. VIII, Proceedings: Concepts and Applications of Systemics, Cybernetics and Informatics II. Orlando, USA: INT INST INFORMATICS \& SYSTEMICS, 2002, p. 344-348. ISBN 980-07-8150-1.

16. Zákon č. 239/2000 Sb. - Zákon o integrovaném záchraném systému.

17. Nařízení vlády č. 430/2006 Sb. - Nařízení vlády o stanovení geodetických referenčních systémů a státních mapových děl závazných na území státu a zásadách jejich používání.

18. Kovařík V. Analysis of Applicability of Web Data Sources for Rapid Mapping at Strategic Command Level. In: International Conference on Military Technologies 2015, ICMT 2015. Brno: University of Defence, 2015, p. 177-182. ISBN 978-80-7231-976-3.

19. Pokonieczny K., Mościcka A. The Influence of the Shape and Size of the Cell on Developing Military Passability Maps. ISPRS Int. J. Geo-Inf. 2018, 7, 261.

20. Cibulová K. The Mobility during Crisis Situations. Key Engineering Materials, 2017, (755), 236-241. ISSN 1013-9826.

21. ATP-3.12.1. Allied tactical doctrine for military engineering. Brusel: NSO, 2016, $158 \mathrm{~s}$.

22. Mazal J. Ženijní (podpora) zpravodajství - Engineer Intelligence. Brno: Univerzita obrany, 2013. ISBN 978-807231-952-7.

23. Pub-31-17-05: Spojenecká taktická doktrína pro ženijní práce podle zásad a principů ATP-3.12.1. Vyškov: Centrum doktrín VeV - VA Vyškov, 2017.

24. KTO 25 (2007). Katalog topografických objektů MoD, Dobruška, Czech Republic.

25. Geoportal CUZK [online]. (C) 2010 [cit. 2020-01-15]. http:// geoportal.cuzk.cz

26. Radimský M. Propustky na pozemních komunikacích. Docplayer. [Online] [Citace: 29. 11 2019.] https:// docplayer.cz/9043395-Propustky-na-pozemnich-komunikacich-michal-radimsky.html. 